\title{
VAPBr: Values in Digital Games for Public Service in Brazil
}

\author{
Fabrício Janssen $^{1}$, Renata Mendes de Araujo ${ }^{2}$, Tadeu Moreira de Classe ${ }^{1}$ \\ ${ }^{1}$ Graduate Program in Informatics (PPGI), Federal University of State of Rio de \\ Janeiro (UNIRIO), Rio de Janeiro, Brazil \\ \{fabricio.janssen,tadeu.classe\}@uniriotec.br \\ ${ }^{2}$ Graduate Program in Applied Computing, Mackenzie Presbyterian University and \\ Graduate Program in Information Systems (EACH), University of São Paulo (USP), \\ São Paulo, Brazil \\ renata.araujo@mackenzie.br
}

\begin{abstract}
In Brazil, many initiatives have emerged to promote the dialogue between citizens and public institutions using technology. This dialogue has been a challenging endeavor, and digital games have been proposed to stimulate interaction and understanding about public service process delivery. In this context, one fundamental aspect observed for the effectiveness of these games is the human values that the games can transmit. This paper proposes the "Values at Play Brazil" (VAPBr), a deck composed of 24 cards as a brainstorming tool to help designers identify values for public process-based digital games. The paper describes the design of VAPBr and its evaluation with 14 game designers aiming to obtain participants' perception of VAPBr capability of clearly describing values and its usefulness for identifying them for a game. Results show a positive perception of VAPBr as a brainstorming tool to discover values to be designed in a public processbased digital game.
\end{abstract}

Keywords: Serious Games Design, Business Process-based Digital Games, Public Services, Values, VAPBr

\section{Introduction}

Several initiatives have emerged worldwide to promote improvements to public administration by facilitating citizens' access to information and services supported by technology [1-5]. Bringing citizens and public institutions closer through technology is a challenge, particularly in Brazil, where the population displays a low level of education (51\% of those with 25 years old or more had only completed elementary school), lack of Internet access (23\% of the population does not have internet access) and low interest or ability to use technology (5\% of the population) [6].

Among the initiatives to shorten the distance between citizens and public services, there are those exploring digital games, assuming that digital games can strengthen democracy and civic participation through social engagement [7- -11$]$. Previous research has demonstrated the feasibility of building digital games from public services' process models. These games can support the citizens' understanding of how the process is performed and delivered [12]. Business process-based digital games are "games with a purpose" (or serious games) that 
playfully present some business processes, allowing players to understand and learn their operation in a fun and engaging manner, developing reflections on their needs, their practice, their values, their challenges and limitations [12]. During this investigation, it was observed that one of the most significant aspects for the effectiveness of these games is their possibility of transmitting human values - moral and ethical principles that guide a person's life - and their potential to allow citizens to reflect on their values concerning public service processes provided.

The idea that values can be incorporated into systems and technical devices (artifacts) has been studied by technological, social and humanities domains [13]. Integrating these values into games is a challenge [14]; this takes on specific contours when the game's purpose is directed to the Brazilian context - due to its culture and diversity. This leads us to the following research question: How can we support game designers to identify values to be designed in digital games based on Brazilian public services?

This research proposes the card deck "Values At Play Brazil" (VAPBr), a brainstorming tool that supports game designers in identifying these values. The methodological approach used in our research was the Design Science Research (DSR), a research process of creating artifacts to solve problems, evaluate what was designed, and communicate the results [15, 16].

The paper describes how VAPBr was built, comprising the identification of values based on Brazilian legal regulations, the design of the card deck, and its evaluation. Based on the DSR, three questions were proposed to verify if VAPBr is feasible to assist game designers in identifying values in this context, concerning to: (1) the VAPBr clarity; (2) the VAPBr usefulness and; (3) the VAPBr as a support tool to put values into game design. We evaluated it with a group of 14 game design students who played VAPBr to select values for a public service business process-based digital game to answer these three questions.

This paper is organized in the following sections. Section 2 presents conceptual background, including open and digital government, business process-based digital games, and values in digital games. Section 3 aims at presenting the methodology - Design Science Research - and the research design. Section 4 describes VAPBr design based on Brazilian law and digital government regulations. Section 5 details VAPBr evaluation - context, planning, execution, and results. Finally, section 6 presents the final remarks.

\section{Background}

\subsection{Open Government}

Open government is defined as a set of government initiatives based on the principles of transparency, integrity, accountability, and stakeholder (including citizens) participation [2, 17]. The interaction between citizens and government through ICTs has been highly explored by governments around the globe, especially in public service delivery and in the involvement of citizens in public policy decision-making [18].

Public organizations have focused on improving and digitizing their services [1, 2], being demanded to innovate through open dialogue with citizens, facilitating service delivery - all the tasks performed by the organization to provide the service, including interaction with citizens [4, 5, 19, 20].

Although there is a thought that society can influence how public services are provided and be motivated by it, it might not reflect this in practice [2, 21]. Facilitating citizens' understanding of public service processes is essential due to their intangibility, which compromises their understanding of how services are provided by institutions, leading them to perceive these services as complicated, bureaucratic, and unnecessary. Understanding the operation, challenges and limitations of a public service delivery process are seen as a crucial point for 
citizens and public institutions to feel confident in dialoguing, discussing, and thinking about improvements and innovations in such services [22-26].

Public organizations occasionally make use of Business Process Management (BPM) approaches [27] to improve their service delivery. BPM is the discipline of analyzing how work is performed to ensure positive results and opportunities for improvement [27]. This knowledge area combines principles, methods, and tools to design, analyze, automate and monitor organizational performance. Business process modeling is an essential task of the BPM life cycle, consisting of the formalization of a diagram representing objectives, actors, activities, execution flow, resources, and products of an organizational process [27].

Some proposals believe that business process models can be the basis for service understanding, transparency, and interaction with citizens [22, 23, 28]. It is assumed that public organizations might use them as an alternative for managing their public service delivery processes [29-31]. Public organizations might benefit from extending their operations to external actors as a public participation innovation endeavor [32, 33]. However, process models are usually technical models. Then, it is necessary to find out manners to help and guarantee citizens' interaction and understand them in a simplified format [22, 34].

\subsection{Business Process-Based Digital Games}

Serious digital games, due to their immersive and engagement potential, have been used in several domains as tools to promote engagement and learning [35-37]. The use of these games is also discussed as a social innovation strategy [8, 38] and gamification is often used as an alternative to encourage citizen collaboration to improve public services [7, 9-11]. This research work is grounded on the idea that serious games can also be thought of as tools for understanding public service delivery processes, enabling citizens to understand the context, difficulties, particularities, challenges, and characteristics of these processes [12].

Previous research has explored the potential of serious digital games to promote understanding of public service business process models by the design of business process-based digital games [12]. Business process-based digital games are games to present a business process in a playful, funny and engaging manner and allow players to understand and learn how the process works, as well as to develop an awareness of the objectives, practices, values, challenges and limitations processes [12, 39]. The design of business process-based digital games is based on the elements which make up the process operation - context, objectives, activities, actors, resources, products, events, rules, and execution flow - translating them into game design elements.

Preliminary evaluations with citizens show that public process-based digital games for discrete public services in Brazil helped players understand the aspects of process execution, being a potential tool to bridge the gap between citizens and public services [12, 39]. However, our study showed a potential problem in the design of these games. In the design process of one of our prototypes, the designer decided to include, as the final game scene, the player killing the secretary responsible for providing the desired service. Defeating (killing) the "boss" (the great enemy in a game) is a prevalent action in digital games, and the designer naturally implemented it into his game. This fact warned us about the importance of discussing the design of games concerning the values involved in the game and the public service.

\subsection{Values in Digital Games}

Rokeach [40] states that values "refers to desirable end-states (...) and the goals one person would like to achieve during his or her lifetime". Schwartz and Bilsky [41] defines values as "concepts or beliefs about desirable end states or behaviors that transcend specific situations, 
guide selection or evaluation of behavior and events, and are ordered by relative importance". Finally, for Hessen [42] "value is the quality of a thing, which can only belong to it due to a subject with a certain awareness capable of registering it". In this research, the sought values are the moral and ethical principles that guide a person's life.

The idea that values can be incorporated into systems and technical devices (artifacts) has been the target of various approaches to studying technology, society, and humanity. If an ideal world is one in which technologies promote not only instrumental values such as functional efficiency, safety, reliability, and ease of use but also social, moral and political values to which societies and their peoples subscribe, those who design systems have a responsibility to take these latter values into account in their work [13].

Kheirandish et al. [43] discuss the role of values to design activities, highlighting, from the literature review, the importance of having a list or framework of values as a reference to supporting designers in identifying the relevant ones to be included in their target products. They propose a framework comprising 200 values obtained from a survey and argued that this is a comprehensive list for guiding value identification in design. Based on this list, Kheirandish et al. [44] developed the HuValue - a card-based design tool to help designers consider human values at different stages of the design process. However, the theoretical ground used in their research comprises mainly literature published in English. Additionally, from the set of respondents, only 7.2\% (about 33 respondents) were South American citizens (not necessarily Brazilian).

Horn [45] argued that games are cultural artifacts that reflect designers' values and may reinforce or challenge players' values. These aspects give games the potential for social change and make us reconsider our relationship with the world. Darzentas and Urquhart [46] point out that game designers and players, as citizens, need systematic critical reflection on social, ethical, and political issues and games are a good starting point for framing and provoking critical discussion around values, being both cultural and educational tools.

Considering precisely values in game design, the work of the American writer and game designer Mary Flanagan is noteworthy. Flanagan has dedicated her career to studying alternatives for game development that can add positive values - both for those who design the games but mainly for those who play them [13]. To address human issues in game design and promote the inclusion of values in design practice, she developed, together with Helen Nissembaum, a methodological framework, called Values at Play (VAP), or "Values at the Game", to promote the integration of values in the design process [13]. The framework comprises three activities: i) Discovery: the activity in which designers discover and identify the relevant values to the project; ii) Implementation: the activity in which the designers translate values into game elements, such as specifications, graphics, and script; and iii) Verification: the activity in which the designers verify that the proposed values were implemented in the game.

One of the essential features of VAP is the card game Grow-a-Game (GaG) [47], a brainstorming tool that helps designers incorporate values into their projects. It has 86 cards, divided into four types: "Values", "Games", "Verbs" and "Challenges". The use of cards as a way to identify relevant values for a game is also explored by Kheirandish and Rauterberg [48], in the HuValue tool; and by Raftopoulos [49], who presents a set of card-based tools to assist in the gamification design process for for business, products, and services.

Cards are used as a common tool for discussing values because many designers search for finding a balance between their values, those of users and other interested parties, and those of the surrounding culture. Therefore, it is essential to have a set of values to start with, and to decide which value must be designed in the game is only possible through an interpretative, collaborative, and brainstorming activity. Therefore, our research decision was to follow this approach by providing a set of values and a card deck to discuss them to design business 
process-based digital games in public service provision, considering Brazilian context and culture.

\section{Research Design}

In this research, we used the Design Science Research (DSR), an epistemological-methodological approach for studying, researching, and investigating the artificial (artifacts) and its behavior, both from the scientific and from the application point of view [16, 50, 51]. In general terms, DSR may be described as a process of thinking and creating artifacts to solve problems, evaluating the designed artifact in its context of use (technologically and scientifically), and communicating the results [15].

The starting point of a typical research based on DSR [52, 53] is the definition of the problem associated with a specific context and a specific audience. The contextualized problem determines the need for an artifact and its requirements. Behavioral conjectures are assumptions about how people behave (learn, work, think, relate, communicate, etc.) reported by theories and literature. Based on these conjectures, the artifact is designed to solve a problem in context. The use of the artifact, through an empirical evaluation, enable us to assess whether the problem has been solved and whether the conjectures that underpin the development of the artifact seem valid. Following this model, our research design can be depicted in Figure 1

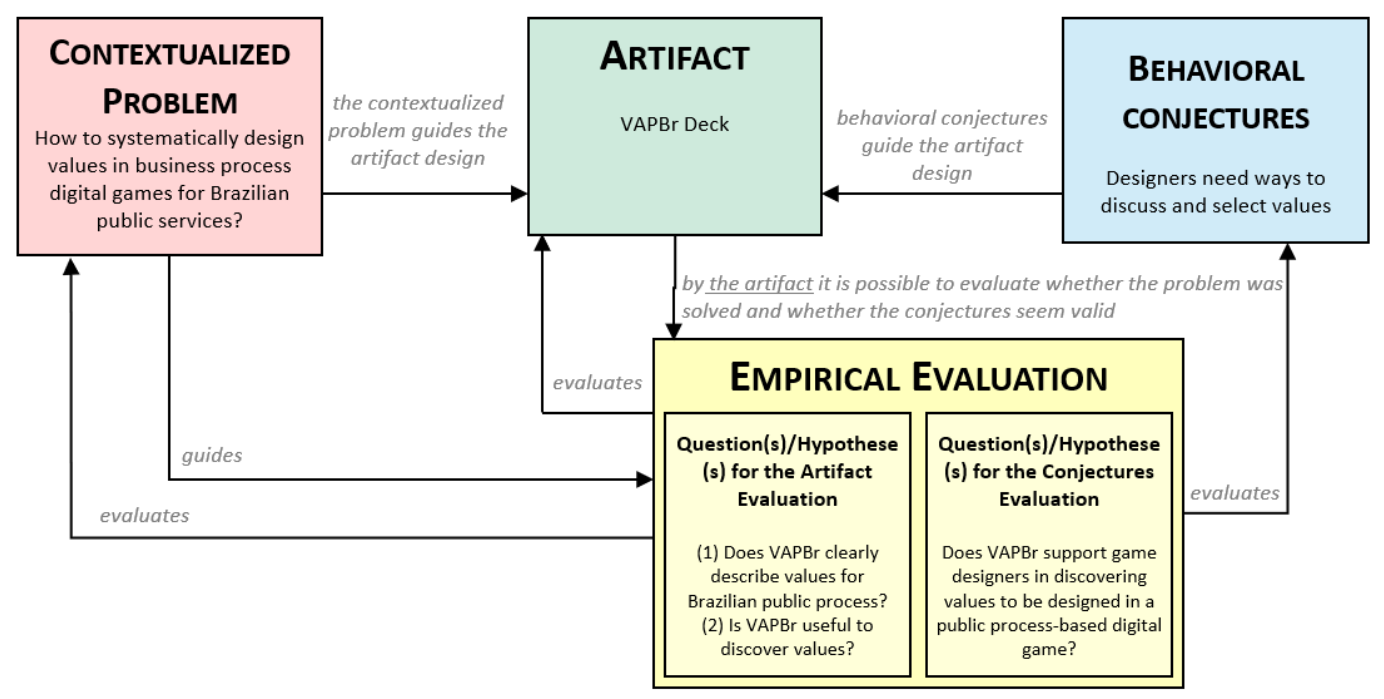

Figure 1: Instantiated research based on central elements of the DSR-Model

In previous sections, open and digital government is our research context, where digital games have been proposed as platforms for citizen-government dialogue. Specifically, we address the design of public service-based digital games, i.e, serious games which implement the public service delivery process and help citizens understand the process by playing the game.Values are essential elements in game design research and practice, as discussed above. Previous experience in designing public process-based digital games shows us the same, where designers included dubious activities into the designed games. Additionally, public institutions must educate and promote better dialogue with citizens concerning public services, and values must be shared in this case. Moreover, in Brazil, the citizen-government relationship is historically and culturally marked by distrust [54, 55]. Therefore, the problem addressed in this research is that public service-based digital games may not fulfill their ob- 
jectives and confuse citizens if values are not judiciously designed and contextualized to the Brazilian context.

As described in Section 2.3, our behavioral conjectures are grounded on the assumptions that values must and can be designed in games if designers have the means to discuss, select and decide about them. Designers can discuss values if an initial set of values are provided to them and reflect or even generate new values to be included in the game depending on the game's purpose and audience. The state of practice in this field is the GaG deck, where a set of values are disposed into cards, and designers may play and discuss them.

An acceptable artifact to solve our research problem could be inspired by GaG, providing a set of values to be designed into public service-based digital games. Using the artifact, game designers should discuss, select and decide about the values that should be included in a game under design. Additionally, the values presented in the artifact must be contextualized to the Brazilian public environment and culture. Therefore, this research proposed the VAPBr card deck to solve the problem of identifying values to be designed in public service-based digital games for Brazilian public services.

An empirical evaluation with game design students was conducted to answer the following questions: (1) Does VAPBr clearly describe values for the Brazilian public process? (2) Is $\mathrm{VAPBr}$ useful to discover values? (3) Does VAPBr support game designers in discovering values to be designed in a public process-based digital game?

The following sections focus on how the artifact VAPBr was designed (Section 4) and on empirical evaluation conducted to verify our assumptions and contribute to the knowledge in the field (Section 5 ).

\section{Values at Play Brazil (VAPBr)}

\subsection{Identifying Values}

We resort to the card game Grow a Game (GaG) [47], a brainstorming tool that helps designers incorporate values in their game designs and as one of the most important resources for designing VAPBr. We started identifying values to be included in VAPBr using the $36 \mathrm{GaG}$ values, as described in Table $1 \mathrm{~A}$.

The following step was about how to specify these values to public processes in Brazil. Our strategy was to analyze Brazilian legal documents and national guidelines for public service delivery, searching for explicit or implicit values. Similar to GaG, based on democratic American principles, our strategy was to identify Brazilian democratic values. We used the primary source for that, the Brazilian Federal Constitution ${ }^{1}$ (BFC), the country's main democracy letter, assuming that, as a democracy, that central public values might be present in the constitution.

We conducted a manual review over the 500 pages of the BFC available on the web to find out if any of the values of our initial list could be explicitly found or if any semantic similarity was found. Sometimes the values could not be found, but sentences meaning them could be identified. This review was highly subjective based on the authors' interpretation (Table 1B). Thirteen of the 36 values proposed in our starting list were found in BFC, and three others were identified based on sentences that express human value ideas. For example, "gender equity" was interpreted as a value from the Art. V, i.I "...men and women are equal in rights and obligations". Another example was "privacy" - "intimacy, private life, honor and people's image are inviolable, and the right to compensation for material or moral damage resulting from their violation is guaranteed" (Art. V, i. X).

\footnotetext{
${ }^{1}$ Brazilian Federal Constitution: http://www.planalto.gov.br
} 
Table 1: Values identified from $G a G, B F C$ and $D G S$ and their combination into proposed values for $\mathrm{VapBr}$

\begin{tabular}{|c|c|c|c|}
\hline A - Values from GaG & B - Values from the BFC & C - Values from the DGS & D - Proposed Values \\
\hline $\begin{array}{l}\text { 1. Accountability } \\
\text { 2. Authorship } \\
\text { 3. Autonomy } \\
\text { 4. Community } \\
\text { 5. Confidence } \\
\text { 6. Cooperation } \\
\text { 7. Creativity } \\
\text { 8. Democracy } \\
\text { 9. Dignity } \\
\text { 10. Diversity } \\
\text { 11. Efficiency } \\
\text { 12. Equality } \\
\text { 13. Freedom } \\
\text { 14. Gender equity } \\
\text { 15. Generosity } \\
\text { 16. Happiness } \\
\text { 17. Humility } \\
\text { 18. Humor } \\
\text { 19. Impersonality } \\
\text { 20. Inclusion } \\
\text { 21. Justice } \\
\text { 22. Legality } \\
\text { 23. Open-mindedness } \\
\text { 24. Peace } \\
\text { 25. Perseverance } \\
\text { 26. Privacy } \\
\text { 27. Respect } \\
\text { 28. Security } \\
\text { 29. Status } \\
\text { 30. Style } \\
\text { 31. Sustainability } \\
\text { 32. Sympathy } \\
\text { 33. Tenacity } \\
\text { 34. Tradition } \\
\text { 35. Trust } \\
\text { 36. Wealth }\end{array}$ & $\begin{array}{l}\text { 1. Accountability } \\
\text { 2. Cooperation } \\
\text { 3. Creativity } \\
\text { 4. Democracy } \\
\text { 5. Dignity } \\
\text { 6. Diversity } \\
\text { 7. Efficiency } \\
\text { 8. Equality } \\
\text { 9. Freedom } \\
\text { 10. Gender equity } \\
\text { 11. Impersonality } \\
\text { 12. Inclusion } \\
\text { 13. Justice } \\
\text { 14. Legality } \\
\text { 15. Privacy } \\
\text { 16. Security }\end{array}$ & $\begin{array}{l}\text { 1. Accountability } \\
\text { 2. Cooperation } \\
\text { 6. Innovation } \\
\text { 4. Privacy } \\
\text { 3. Security } \\
\text { 5. Simplicity } \\
\text { 7. Social participation }\end{array}$ & $\begin{array}{l}\text { 1. Accountability } \\
\text { 2. Cooperation } \\
\text { 3. Creativity } \\
\text { 4. Democracy } \\
\text { 5. Dignity } \\
\text { 6. Diversity } \\
\text { 7. Efficiency } \\
\text { 8. Equality } \\
\text { 9. Freedom } \\
\text { 10. Gender equity } \\
\text { 11. Impersonality } \\
\text { 12. Inclusion } \\
\text { 13. Innovation } \\
\text { 14. Justice } \\
\text { 15. Legality } \\
\text { 16. Privacy } \\
\text { 17. Security } \\
\text { 18. Simplicity } \\
\text { 19. Social participation }\end{array}$ \\
\hline
\end{tabular}

Note 1: GaG (Grow a Game), BFC (Brazilian Federal Constitution) and DGS (Digital Governance Strategy).

Additionally, we conducted the same procedure to find values explicitly or implicitly included in the Federal Government's Digital Governance Strategy $2{ }^{2}$ (DGS), enacted in 2016 and renewed in 2020. DGS defines the main principles and guidelines for public service digitization that all Brazilian public agencies must observe.

DGS organizes government agencies' digital transformation guidelines into three main areas: Information Access; Service Provision; and Social Participation. The document comprises ten principles that guide digital governance activities, where it was possible to identify seven values, presented in Table $1 \mathrm{C}$. The first four values were already identified in our previous list and three new values arose: simplicity, innovation, and social participation.

A combination of the identified values was organized in a final list (Table 1D), comprising our first attempt of relevant values to be discussed when designing games for public processes in Brazil.

\footnotetext{
${ }^{2}$ Federal Government's Digital Governance Strategy: https : / /www.gov .br/
} 


\subsection{VAPBr Card Deck}

The second issue we tried to address to build our artifact was about which tools could support designers in deciding about the values to be included in a game design. We addressed this issue by developing the VAPBr Card Deck, inspired by GaG.

VAPBr Card Deck comprises the 19 values previously identified and five wildcards, totaling 24 cards (Figure 2). The reason for including wildcards is related to the opportunity to include other values which may arise during the discussion regarding specificities of the public service context being studied. The 19 cards hold a brief abstract and an extended description of each value, minimizing the risk of multiple interpretations. The descriptions of the values were extracted from several sources, such as BFC and government websites in Brazil. A detailed description of each card can be found in Appendix 1 and the current version of VAPBr is available online 3 .

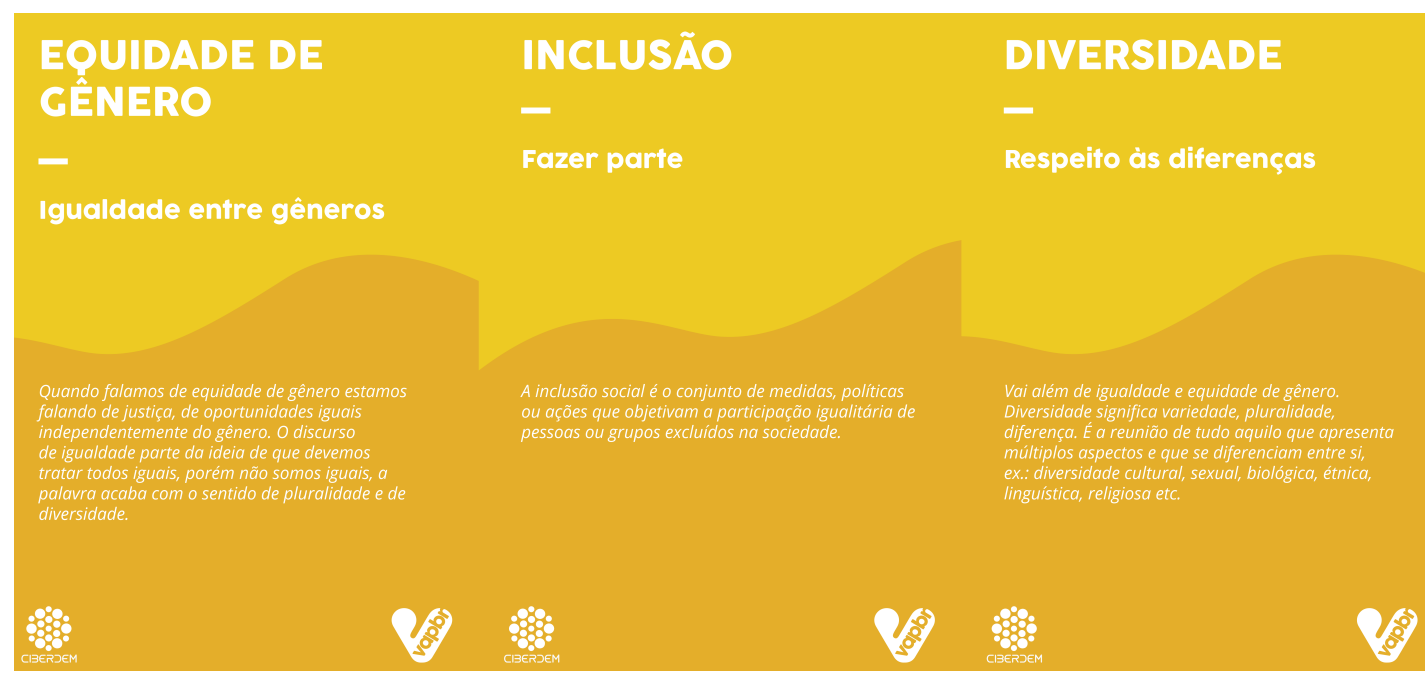

Figure 2: $V A P B r$ Cards Examples (In their original language: Portuguese)

\subsubsection{How to Play}

To address the issue of how designers can discuss values over a specific game design, we defined a sequence of steps to help designers "discover values" to be designed into the game. Initially, groups of 3 to 5 people should be formed. They can assume 4 roles: Game Design Team - digital game design team; Development Team - programmers, analysts, musicians, artists, etc; Target Audience - citizens and users of the service; or Process Executors - process executors, directors, managers.

The following step is a suggested dynamics for a VAPBr playing session. The team may be divide into groups (3-5 participants). In a first round, ideally lasting up to 15 minutes, each group receives different subsets of values from VAPBr, each subset containing the same number of cards. This first brainstorm round aims to raise information about the public organization objectives, main difficulties in service provision, citizens' perception, and any other helpful information to be transmitted in the digital game. In the end, each team must discard at least half of their initial cards.

In a second round, the groups are recombined, creating larger groups than before and mixing the players as much as possible. Each new team must discuss for 10 minutes which values identified in the preceding phase must go into the game. The team can choose up to

\footnotetext{
${ }^{3}$ Available for download at: https://ciberdem.mack.com.br/index.php/jogos/
} 
half of the available values. Values that are not voted on are discarded. Those values voted by all groups are immediately approved. A new debate lasting up to five minutes among all participants will decide whether any values that were not unanimous among the team members should be selected or not.

Two observations must be made: (1) Depending on the need, the rounds can be longer or shorter; (2) It is also up to the players to decide whether to create intermediate rounds so that there is the possibility of deepening the discussions. The rules for using the game are flexible and can be adjusted according to the team profile.

\section{Evaluating $\mathrm{VAPBr}$}

Seeking to examine to which extent these solutions can be effectively used in a game design setting and whether it could help game designers find out values for designing a business process-based digital game, game design students were invited as evaluators.

We used the GQM (Goal Question Metric) paradigm [56] to describe the evaluation objective regarding the issues concerning each research question: (1) Does VAPBr clearly describe values for the Brazilian public process? - clarity (2) Is VAPBr useful to discover values? usefulness; and (3) Does VAPBr support game designers in discovering values to be designed in a public process-based digital game? - support. Therefore, the aim of the evaluation can be stated as: Analyzing VAPBr, with the purpose of evaluation; regarding 1) clarity to describe values; 2) usefulness to the discovery of values; and 3) help designers discover values for a digital game design; from the point of view of game design students; in the context of digital games based on Brazilian public service processes.

\subsection{Context}

The study was contextualized in designing a business process-based digital game for the Police Department (PD) in Rio de Janeiro, Brazil. The public process selected for this study has the objective of investigating missing people in the State, where about 400 people disappear every month and the so-called vulnerable population presents a higher incidence of cases: 4 : the missing person profile is 52\% black and brown, $38.53 \%$ between 18 and 29 years old, $13.62 \%$ between 12 and 17 years old, low income and education.

The service and its steps are usually unknown by citizens [57], which leads to confusion and disappointment in service provision. Based on interviews with police representatives at the missing person police department (DDPA), it was possible to model the process (Figure 3), and design a game based on this model: The Missing Person Game 5

The Missing Person Game puts the player into the role of an investigator at the police department (Figure 4), and he/she must correctly perform the process tasks while he/she attends to different citizens reporting missing cases. The game allows the player to experience the process performed in the police department, using the available resources and facing the process challenges and difficulties to collect information about the missing person. Such as in the real process, the officer must calm down the citizen while he/she tries to get enough information (e.g., ID, address, eyes color, skin, birthmarks, and clothes) to find the person as fast as possible. The game success happens when the player finds the missing person by performing the right tasks.

\footnotetext{
${ }^{4}$ Social Development and Human Rights of the State of Rio de Janeiro: http://www.rj.gov.br/ secretaria/NoticiaDetalhe.aspx?id_noticia=3301

${ }^{5}$ Missing Person Game: http://gpjc.uniriotec.br/games/desaparecidos
} 


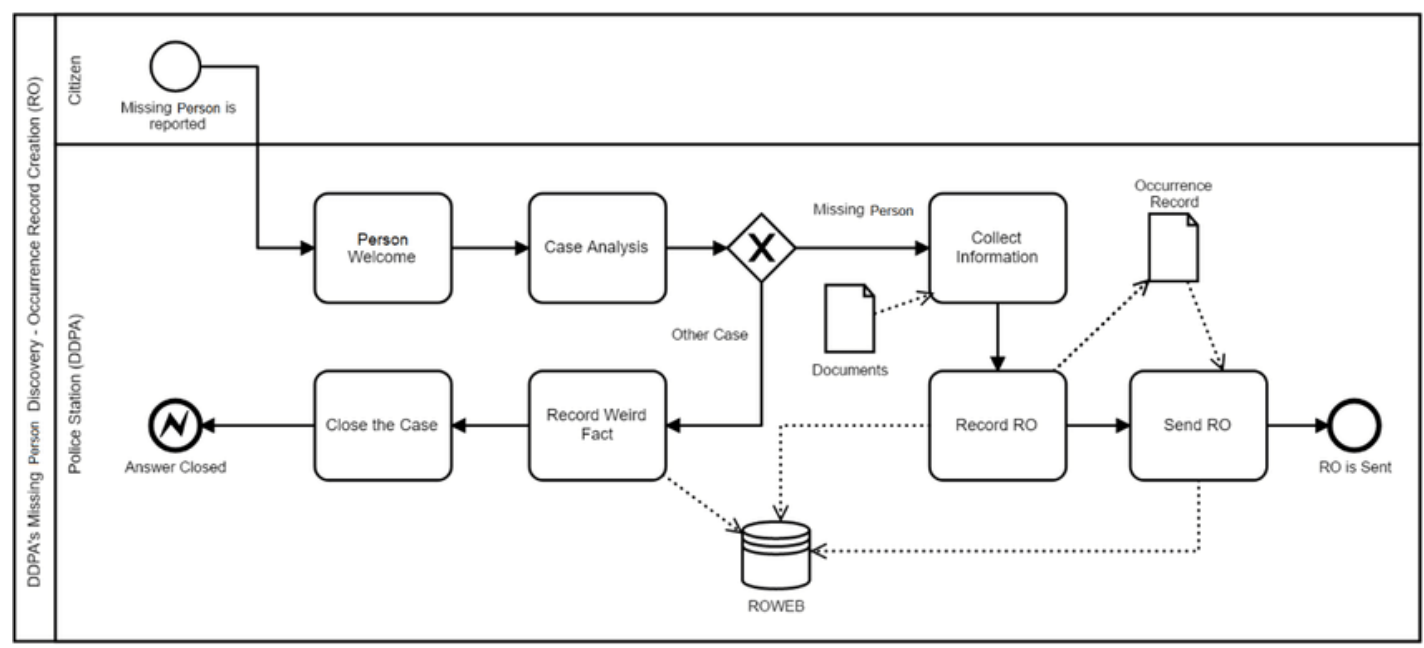

Figure 3: The Missing People Service in the BPMN Model

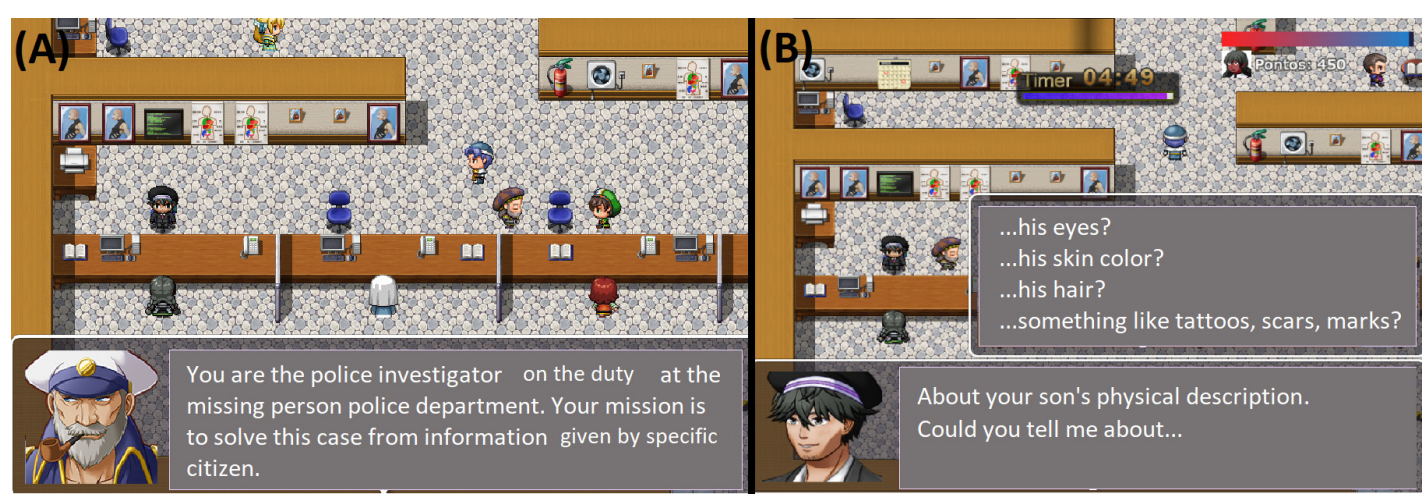

Figure 4: The Missing Person Game

\subsection{Planning}

The evaluation process was carried out regarding the values to be designed into the Missing Person Game. The participants should: 1) put themselves as game designers and identify relevant values for the missing person public service, based on the process model; 2) discuss the identified values and elaborate a list of values to be designed in the game; and 3) answer a questionnaire related to the clarity, usefulness, and support regarding VAPBr.

\subsubsection{Participants}

A total of 14 participants were selected by convenience, comprising students from an Information Systems undergraduate game design class. They were all end-of-course students with maturity and competence in the technical field. The study was performed at the end of the game design course after designing both serious and entertainment games on their own. Additionally, they are all Brazilian citizens who eventually use public services, although they never needed to use the missing process service before.

An important aspect is that students enroll in the course voluntarily, demonstrating interest in the game design theme. So, they did not receive any reward for participating. 


\subsubsection{Study Steps}

The study was planned to be carried out in one session comprising the five activities (A1 to A5) related to the VAPBr's playing steps, as shown in Table 2. The first three activities were: A1) to explain the study objectives; A2) to explain about values and public services; and A3) to explain about how to use $\mathrm{VAPBr}$ (as described in section 4.2.1 above), totaling 30 minutes. In the next activity (A4), participants used VAPBr to identify the values for the Missing Person Game based on the process model described in Figure 3 (50 minutes). In the final activity (A5), participants answered an anonymous questionnaire (15 minutes).

Table 2: $V A P B r$ evaluation schedule

\begin{tabular}{|c|c|l|c|}
\hline$\#$ & Duration & Activity & Type \\
\hline A1 & $10 \mathrm{~min}$. & Study objectives explanation & Presentation \\
\hline A2 & $10 \mathrm{~min}$. & Explanation about Values and Public Service & Presentation \\
\hline A3 & $10 \mathrm{~min}$. & VAPBr rules explanation & Presentation \\
\hline A4 & $50 \mathrm{~min}$. & $\begin{array}{l}\text { Use of VAPBr - values identification for the public ser- } \\
\text { vice }\end{array}$ & Groups \\
\hline A5 & $15 \mathrm{~min}$. & Questionnaire & Individual \\
\hline
\end{tabular}

\subsubsection{Data Collection}

A questionnaire was built considering collecting data focusing on the research issues about the VAPBr clarity, usefulness, and support. The questionnaire comprised close-ended questions (Likert's Scale), which allowed us to summarize answers in descriptive statistics (percentage and mode). For each close-ended question, an open field for comments was provided (openended question), where the participants could comment on their answers. The questionnaire was built using Google Forms, and participants did not communicate among them while filling the form. Moreover, we followed the session by observing and analyzing the progress of the values identified by the students.

\subsubsection{Threats to Validity}

This study is subject to several threats to validity. The main threats to the construct validity were: i) the bias in the data selection used in data analysis: it happens when a researcher can favor his conclusions by listing only data which point to them. To minimize it, the closedended answers were analyzed comparing with their open-ended answers (if it was available). Also, to allow the study reproducibility and consultations by other researchers, participant's answers are available online 6 ii) study instrumentation: in general, it occurs when the study instruments (questionnaires and forms, for instance) are not adequate to study aims, causing errors in data collection, analysis, and in the study conclusions. To mitigate it, the questionnaire statements were based on the Technology Acceptance Model [58], and it was submitted to pilot evaluation prior to the main study.

The main threats of internal validity were: i) the time expended in the study: this threat is related to participant's fatigue. To avoid it, all steps were performed within a time limit, and all study was designed within a class time limit; ii) threat of morality: it is related to personal gains and positive reinforcements offer to the study participants. Even though all participants were students, the volunteer participation was clear since the beginning of the study. iii) threat of training: sometimes, the absence of training can lead participants to misperceive the study and change conclusions. Thus, to decrease this threat, we explained the VAPBr in detail, and we gave some examples that could be used with the participants.

\footnotetext{
${ }^{6}$ Participant's answers: https://bit.ly/36rpIWM
} 
About threats of external validity and reliability, they concern the evaluation planning that was planned following the planning steps of the case study described by [59].

\subsection{Execution}

\subsubsection{VAPBr Playing Session}

The students were divided into three groups, two groups with five members and one with four members. The participants were informed about the possibility of performing longer or shorter rounds, if needed, and that it was up to them to decide whether to create intermediate rounds. They only had the model of the missing person process and the VAPBr cards to conduct the discussion.

The $24 \mathrm{VAPBr}$ cards were shuffled and distributed equally to each team. In this case, each group was left with eight cards. In the first round, each group should discard half of their cards. Group A, the only one with four people, received a wild card. Group B, three wild cards. The fifth wild card went to Group C. Except for group A, which used only five minutes to conclude which values should remain in the game, the others used the available 15 minutes. The values chosen by each group are in Table 3, where the wildcards are highlighted in bold.

Table 3: Values approved and disapproved by each group

\begin{tabular}{|c|l|l|}
\hline Group & Approved & Disapproved \\
\hline A & $\begin{array}{l}\text { Social Participation - Legality - Ac- } \\
\text { countability - Accessibility }\end{array}$ & $\begin{array}{l}\text { Freedom - Creativity - Efficiency - } \\
\text { Gender Equity }\end{array}$ \\
\hline B & $\begin{array}{l}\text { Simplicity - Security - Efficiency - } \\
\text { Accountability }\end{array}$ & $\begin{array}{l}\text { Privacy - Justice - Equality - Wild- } \\
\text { card }\end{array}$ \\
\hline C & $\begin{array}{l}\text { Innovation - Dignity - Cooperation - } \\
\text { Honesty }\end{array}$ & $\begin{array}{l}\text { Democracy - Inclusion - Diversity - } \\
\text { Impersonality }\end{array}$ \\
\hline
\end{tabular}

The three groups had to discuss which cards of those obtained in the first round would be essential for the next round. Ideally, groups should be mixed to leverage mutual interaction. However, instead of being mandatory, this decision was submitted to the class, who preferred to continue their respective groups. Again, they were asked to cut the number of cards by half. Participants were, then, asked to choose up to four values from the list of 11 values approved in the first phase: Social Participation, Legality, Cooperation, Accountability, Accessibility, Honesty, Simplicity, Security, Efficiency, Innovation and Dignity.

The groups gathered for 10 minutes and were asked only to avoid voting for their values, as there was no group reorganization. Group A voted for: Social Participation, Legality, Accessibility and Simplicity. Group B chose: Security, Efficiency, Accountability and Cooperation. Finally, Group $\mathrm{C}$ decided to vote for only 3 values: Accountability, Cooperation and Accessibility. Accountability, Cooperation and Accessibility were the most voted values, although there was no unanimity. The cards Innovation, Dignity e Honesty did not receive any votes and were discarded.

The goal was to reach the end of the discussion, with the 24 cards being reduced to only 6. The participants decided that each group should choose one in five left values. Legality and Simplicity were discarded and each group voted for, respectively: Social Participation, Efficiency and Security, completing the list of six values. The selection trajectory can be checked in Table 4

\subsubsection{Questionnaire}

After playing VAPBr, the participants were asked to fill the questionnaire. Two participants chose not to answer it. Thus, 12 responses were analyzed. Only percentage and mode analysis 
Table 4: Selection trajectory of the VAPBr cards (A, B, and C - Groups)

\begin{tabular}{|c|c|c|c|}
\hline Values (Cards) & 1st Round & 2nd Round & Final Round \\
\hline Accountability & $\mathrm{A}, \mathrm{B}$ & $\mathrm{B}, \mathrm{C}$ & $\mathrm{X}$ \\
\hline Legality & $\mathrm{A}$ & $\mathrm{A}$ & \\
\hline Security & $\mathrm{B}$ & $\mathrm{B}$ & $\mathrm{X}$ \\
\hline Efficiency & $\mathrm{B}$ & $\mathrm{B}$ & $\mathrm{X}$ \\
\hline Simplicity & $\mathrm{B}$ & $\mathrm{A}$ & \\
\hline Justice & & & \\
\hline Equality & & & \\
\hline Privacy & & & \\
\hline Gender Equity & & & \\
\hline Diversity & & & \\
\hline Inclusion & & & $\mathrm{X}$ \\
\hline Democracy & & & $\mathrm{X}$ \\
\hline Social Participation & $\mathrm{A}$ & $\mathrm{A}$ & \\
\hline Dignity & $\mathrm{C}$ & & \\
\hline Cooperation & $\mathrm{C}$ & $\mathrm{B}, \mathrm{C}$ & \\
\hline Creativity & & & \\
\hline Impersonality & & & \\
\hline Innovation & $\mathrm{C}$ & & \\
\hline Freedom & & & \\
\hline $\begin{array}{c}\text { Wildcard 1 Class } \\
\text { (Accessibility) }\end{array}$ & $\mathrm{A}$ & $\mathrm{A}, \mathrm{C}$ & \\
\hline Wildcard 2 Class (Honesty) & $\mathrm{C}$ & & \\
\hline
\end{tabular}

(descriptive statistical) of the questions was made and Table 5 represents the participant's answers according to their opinion and perception of $\mathrm{VAPBr}$.

The questionnaire comprised 18 statements and for each statement, the participants should express their degree of agreement, considering: $1=$ Totally disagree $\mid 2=$ Disagree $\mid 3=I$ don't know $\mid 4=$ Agree $\mid 5=$ I totally agree. For each statement, an open field allowed participants to comment on their answers if desired. Therefore, it was possible to collect quantitative (degree of agreement) and qualitative data (comments).

The statements were elaborated based on the Technology Acceptance Model [58] and according to the study objectives, as described in the GQM proposed for the study: (1) clarity of VAPBr cards and rules; (2) the usefulness of the VAPBr deck; (3) and the participants' attitude to use it in the future. A statement to collect participants' perceptions about the time spent was also included - the duration of the VAPBr round. The results are in Table 5, and the column Mode represents the mode or the most typical value, i.e., the most frequent answer.

In the following paragraphs, we summarize the results for each evaluation dimension and statements collected through the questionnaire and participants' comments which we eventually understood as relevant to analyze and discuss the results. According to the duration, Statement \#1 -"VAPBr has an adequate duration", the respondents were friendly, as $66.6 \%$ indicated 4 ("Agree") or 5 ("Totally Agree"). This shows the use of VAPBr has an adequate time when applied in a group. However, one participant observed: "Depending on the the number of people, it can be very slow and time-consuming". Considering that people have different values, the discussion provided by VAPBr could be long and exhaustive until they reach a consensus.

Based on the questions about clarity (Statements \#2 to \#9), it is observed that participants agree with all the statements (mode $4=$ "Agree"), i.e. participants evaluate VAPBr as clear. Although they state that VAPBr is sufficient to discuss values for the game, being eased to use and not bringing difficulties to the process, they also reported the need for obtaining more information on each value - description and examples. For instance, regarding the questionnaire 
Table 5: Participant's perception about the use of $\mathrm{VAPBr}$

\begin{tabular}{|c|c|c|c|c|c|c|c|c|}
\hline Assessment & $\#$ & Statement & 1 & 2 & 3 & 4 & 5 & Mode \\
\hline Duration & 1 & VAPBr has an adequate duration & $0 \%$ & $16,7 \%$ & $16.7 \%$ & $58.3 \%$ & $8.3 \%$ & 4 \\
\hline \multirow{8}{*}{ Clarity } & 2 & VAPBr has objective rules & $0 \%$ & $0 \%$ & $0 \%$ & $58.3 \%$ & $41,7 \%$ & 4 \\
\hline & 3 & $\begin{array}{l}\text { The values present in the VAPBr } \\
\text { cards are sufficient for the game }\end{array}$ & $0 \%$ & $16.7 \%$ & $25 \%$ & $33.3 \%$ & $25 \%$ & 4 \\
\hline & 4 & $\begin{array}{l}\text { The description of the Values } \\
\text { present in the VAPBr cards was } \\
\text { sufficient to complete the game }\end{array}$ & $0 \%$ & $16.7 \%$ & $25 \%$ & $33.3 \%$ & $25 \%$ & 4 \\
\hline & 5 & $\begin{array}{l}\text { It was necessary to use the } \\
\text { extended description in the } \\
\text { spreadsheet to understand a little } \\
\text { more about the values }\end{array}$ & $8.3 \%$ & $8.3 \%$ & $0 \%$ & $41.7 \%$ & $41.7 \%$ & 4 and 5 \\
\hline & 6 & $\begin{array}{l}\text { It was necessary to use the } \\
\text { examples in the extended } \\
\text { description to think about the } \\
\text { values }\end{array}$ & $0 \%$ & $8.3 \%$ & $16.7 \%$ & $66.7 \%$ & $8.3 \%$ & 4 \\
\hline & 7 & $\begin{array}{l}\text { There were not many difficulties } \\
\text { during the VAPBr match }\end{array}$ & $0 \%$ & $8.3 \%$ & $16.7 \%$ & $41.7 \%$ & $33.3 \%$ & 4 \\
\hline & 8 & $\begin{array}{l}\text { I didn't make many mistakes and } \\
\text { got involved properly during the } \\
\text { match }\end{array}$ & $0 \%$ & $0 \%$ & $8.3 \%$ & $66.7 \%$ & $25 \%$ & 4 \\
\hline & 9 & I think VAPBr is easy to use & $0 \%$ & $0 \%$ & $0 \%$ & $50 \%$ & $50 \%$ & 4 and 5 \\
\hline \multirow[t]{5}{*}{ Usefulness } & 10 & $\begin{array}{l}\text { VAPBr game is useful for setting } \\
\text { values for a game project in its } \\
\text { context }\end{array}$ & $0 \%$ & $0 \%$ & $16.7 \%$ & $25 \%$ & $58.3 \%$ & 5 \\
\hline & 11 & $\begin{array}{l}\text { VAPBr made the discussion for } \\
\text { raising values efficient }\end{array}$ & $0 \%$ & $0 \%$ & $8.3 \%$ & $25 \%$ & $66.7 \%$ & 5 \\
\hline & 12 & VAPBr is dynamic & $0 \%$ & $0 \%$ & $25 \%$ & $25 \%$ & $50 \%$ & 5 \\
\hline & 13 & $\begin{array}{l}\text { VAPBr allowed all the players to } \\
\text { be involved }\end{array}$ & $0 \%$ & $0 \%$ & $0 \%$ & $50 \%$ & $50 \%$ & 4 and 5 \\
\hline & 14 & $\begin{array}{l}\text { I approve the list of values raised at } \\
\text { the end of the match }\end{array}$ & $0 \%$ & $8.3 \%$ & $8.3 \%$ & $16.7 \%$ & $66.7 \%$ & 5 \\
\hline \multirow[t]{4}{*}{ Attitude to Use } & 15 & $\begin{array}{l}\text { I intend to use VAPBr in my game } \\
\text { projects, if the discussion of values } \\
\text { is raised }\end{array}$ & $0 \%$ & $0 \%$ & $66.7 \%$ & $16.7 \%$ & $16.7 \%$ & 3 \\
\hline & 16 & $\begin{array}{l}\text { I intend to discuss values whenever } \\
\text { possible in my game projects with } \\
\text { purpose }\end{array}$ & $0 \%$ & $0 \%$ & $16.6 \%$ & $41.7 \%$ & $41.7 \%$ & 4 and 5 \\
\hline & 17 & VAPBr is fun & $0 \%$ & $8.3 \%$ & $33.3 \%$ & $33.3 \%$ & $25 \%$ & 3 and 4 \\
\hline & 18 & I recommend using VAPBr & $0 \%$ & $0 \%$ & $16.7 \%$ & $25 \%$ & $58.3 \%$ & 5 \\
\hline
\end{tabular}

Note 1: A total of 14 participants participated of the study, even though only 12 answered the survey.

Note 2: The columns named from 1 to 5 are related to participant's degree of agreement: $1=$ Totally disagree $\mid 2=$ Disagree $\mid 3$

$=\mathrm{I}$ don't know $\mid 4$ = Agree $\mid 5=$ I totally agree .

Statement \#5 - "It was necessary to use the extended description in the spreadsheet to understand a little more about the values." - we had a tie between "Agree" and "I totally agree" ( $41.7 \%$ each, $83.4 \%$ total). It could demonstrate the need of the participants to understand the meanings of the values better.

Additionally, for Statement \#3 - "The Values present in the VAPBr cards are sufficient for the game." and in Statement \#4 - "The description of the values present in the VAPBr cards was sufficient to complete the game", the agreement dropped to $58.3 \%$. We observed that the decrease was due to the fact that the participants need more elements than only values names to complete the game design. They need contextualized information, detailed description, and some example of applications in order to choose the best value, such as mentioned by a participant: "Some values were not clear enough only with their descriptions [...], each person thought that a card meant different things. But, the application examples helped us to clarify differences such as security and social inclusion, for instance.". On the other hand, about the VAPBr rules, $100 \%$ of the respondents agreed with the Statement \#2 - "VAPBr has objective rules", implying that the rules and the game dynamics were clear. the Statement \#9 - "I think VAPBr is easy to use", $100 \%$ of participants scored 4 or 5 (mode). Although we observed that 
there is the need for more detailed card description and examples, the respondents' results indicate that VAPBr is clear and easy to use.

Regarding usefulness - Statements \#10 to \#14 - participants agreed (the most frequent mode $=5$ ), reporting their perception of VAPBr usefulness to identify relevant values and improve group discussion. One of the most important statements, Statement \#10 - "VAPBr game is useful for setting values for a game project in its context" reached 58.3\% of "Totally Agree" answers. It indicates that the participants agreed that $\mathrm{VAPBr}$ helps identify values. $\mathrm{VAPBr}$ was also perceived as useful for discussing values; $66,7 \%$ of the answers to Statement \#11 "VAPBr made the discussion for raising values efficient" were "Totally Agree". When using VAPBr, participants seemed engaged in the values discovering task. This is reflected by the answers to Statement \#13 - "VAPBr allowed players to be involved", being by $100 \%$ of agreement. In all of the statements concerning usefulness, no one scored 1 ("Totally Disagree") or 2 ("Disagree").

Concerning attitude to use, Statements \#15 to \#18, participants perceived the relevance of using VAPBr as tool for discussing values. However, they still do not perceive VAPBr as fun or show an entirely positive attitude towards using it again. Statement \#15 ("I intend to use VAPBr in my game projects if the discussion of values is raised."), for example, revealed that $66.7 \%$ of the participants do not know if they would use VAPBr in their future game designs. And, also, Statement \#16 ("I intend to discuss values whenever possible in my game projects with purpose") shows that around $83,4 \%$ of participants would discuss values in games with purpose projects if they have some chance. However, the mode of Statement \#18 - "I recommend using VAPBr" is 5, which shows that participants would indicate VAPBr in game design that involves values. When referring to the use of VAPBr for the discussion of values, the agreement falls. Statement \#17 - "VAPBr is fun", received answers "I don't know" and "Agree" (33.3\% both). In general, the mode of participant's answers varied between 3 ("I don't know") and 5 ("I Totally Agree"). Even though these values approach a high level of agreement, it is necessary to investigate and improve the participant's perception in terms of intention to use and make the VAPBr more fun.

\subsection{Answering Research Questions}

The analysis and results described above allow us to answer our research questions as follows.

(1) Does VAPBr clearly describe values for the Brazilian public process?

Participants were able to identify a set of relevant values for the missing person process and game. To perform this selection, they needed to understand what values could be used and their meaning. VAPBr helped them by providing a set of Brazilian public service values with descriptions and examples of use that were sufficient for discussion, reflection, and selection of the relevant ones to be designed in the game. In all statements (\#2 to \#9), affirmative responses (4 or 5) exceeded 50\% of agreement among the study participants.

However, values are such a subjective concept that even if we provide more and more explanations about their meaning, they will still be interpreted differently by each person. As mentioned by one participant: "In the final discussion, it seemed to me that several choices were made in confusion, each person thinks that a value wanted to say something". In contrast, one student commented: "Most of it is already very clear on its own". Additionally, values could be interpreted according to each onet's personal involvement with the service, reinforcing the importance of having different actors together during the discussion of values to be implemented in the game. 
(2) Is VAPBr useful to discover values?

Participants could identify, describe and discuss values for the missing person process/game. They easily produced lists of values to guide brainstorming and discussion about the game design. This is shown by the answers reported in Statements \#10 to \#14, which discuss VAPBr usefulness. In all statements, affirmative responses (4 or 5) exceeded $75 \%$ of agreement among the participants.

Participants answered that VAPBr helped them think about the values, identify and discuss them collaboratively as a game design brainstorming session: "The game encompasses very broad values, which can be very difficult to write in just one card, but there is a very good dynamics for making decisions and instigating the argument of each value. It helped a lot for the team decision, preparing the group to justify the reasons for their decisions", wrote one of them.

Other participants answered: "The VAPBr is an efficient way to support the debate about what values should be explored in certain game context" and "It is important to think in values at the beginning of the game project to guide the game design [...] VAPBR made this task dynamics, which lead us to think (in values) in a way that we did not think before.". We think that the participant's answers support this research question. Therefore, it is possible to say that VAPBr is useful to discover values in the game design process.

(3) Does VAPBr support game designers in discovering values to be designed in a public process-based digital game?

Based on the evaluation results and the values enumerated in Table 4, it is possible to observe that participants could follow the entire process of raising values which served as the basis for the game design. Participants highlighted: "There are very broad values in the game, and there is very good dynamics for decision. It helped a lot in the team decision and left the group prepared to justify the reason of their decisions". In his perception, the VAPBr helped identify and discuss values of the public service. One participant partially disagreed: "I think the game works a lot to stimulate discussions to raise values to be addressed. However, I don't know if it is more efficient than a brainstorm, for example". We understand that point of view. Flanagan [13], for example, claims that people should start from general values, based on their personal experiences, when participate in brainstorming design meetings. However, the most significant difference in using VAPBr to discuss public process-based digital games is that VAPBr starts with values which are mentioned in key documents of the Brazilian public administration, and consequently, values that may be reflected in the public services. Additionally, VAPBr guides game designers interpretating each value providing an explanation, in a short sentence, about the value; an extended description of the use of that value; and an example of applying that value in a public service context.

Kheirandish et al. [44], in their research, discussed the role of values in the design activities, approaching a list of relevant values as references to support designers (not only game designers) in the design of their products. They proposed the HuValue tool to help designers to consider human values in their design process. It is precisely what the VAPBr does, but for serious games based on Brazilian contexts. Our approach of values is supported by the Brazilian laws, reports, and governmental documents. As Kheirandish et al.'s research, we gathered a list of values and presented them to game designers as a card game to understand the fundamental Brazilian values. Thus, as explained in the answers above, we had clues that 
VAPBr can help designers identify and discuss Brazilian public service processes' values, being a helpful tool.

On the other hand, it is necessary to consider the subjectivity of values for each individual. Flanagan [13], Darzentas and Urquhart [46] and Horn [45], in their research, spoke about that. Games, as cultural artifacts, reflect the designer and the players' values. We could perceive their values in the game. Everyone has their perception of values. It is not different using VAPBr. In our study, problems regarding the values' subjectiveness appeared. According to a participant of our study: "I just wonder if values cannot become subjective in some way, since some people value more fundamentalistic values that do not match other values such as plurality, equity, equality". And it is true, even though we provided a list of values and their description based on formal documents, the interpretations of their meanings are individual. The VAPBr is a starting point for discussing Brazilian public services values and decreasing this subjectiveness, but we understand it is challenging.

However, considering persons' individual values, the inclusion of wildcards, as in the $\mathrm{GaG}$, showed to be an important and correct decision in this study. Belman et al. [47] included wildcards in the GAG deck to encourage participants to add values that reflect their world views and commitments. In this study, we observed the use of the wildcards by all groups (as presented in Table 3). It seemed like, using these cards, they could externalize their values, and it allowed them to increase their engagement and sense of participation in the discussion about the issue. Therefore, game designers should discuss values if an initial set of values are provided to them and if they can reflect or even generate new values to be included in the game depending on the game purpose and audience. As pointed by a participant: "It is essential to think about the values at the beginning of the game project to guide its purpose and avoid misunderstandings. The VAPBr dynamics made this activity (think about values) easier, making you consider things untaught in the first moment".

\section{Conclusion}

This article presented the card deck "Values At Play Brazil" as a brainstorming tool that aims to support game designers in identifying and discussing values from Brazilian public services. The article described how the VAPBr was built and evaluated using a study to verify its clarity, usefulness, and if it helps game design in the values discovery task. Our main research question How can we support game designers to identify values to be designed in digital games based on Brazilian public services? could be answered in this study. It was possible to observe that game designers can use the VAPBr to discover and discuss values from the public process, to put them into the game design process. The VAPBr was clear and useful for the discovery task, although there is still opportunity to make its use more engaging and fun. The study also showed that discussing values is a very challenging task, due to is subjectivity and more research is needed to investigate its impact in the design process as well as to designers' and players' beliefs and perceptions.

This research work can contribute to the Brazilian game design industry and open government initiatives once VAPBr may help designers and public servants be "sensitized" with the importance of passing positive values to players. It also contributes to a serious game design research area by proposing a set of values and a tool to discuss them within a specific game genre and cultural context. We hope these results may bring more knowledge to the game values research. This work also contributes to the public service business process-based digital games research by proposing one way to include values in these games.

As a limitation, the research evaluation was based on a specific context from a Brazilian public service process. It is necessary to carry out new studies using other public services to 
pag. 42

examine if the VAPBr supports the task of values discovery. We also did not design a full game in this study. At the moment, we only investigated if it would be possible to discover values from public services and if they could be used in the game design process, using a brainstorming tool as support. It seems the answer to these questions are positive. Finally, the VAPBr evaluation presented in the paper was performed by game design students. In this case, to generalize our findings, it would be necessary to plan another study with a professional game design team, collecting their perceptions, and compare the answers with the previous research.

As future work, different experiments with players are mostly welcome. For instance, to evaluate how players perceive values before and after playing the game, or how they perceive values in games designed with or without VAPBr. Furthermore, deep studies on how games designed with VAPBr impact playerst' behavior are a longterm step of this research.

One insight that emerged from our findings was that VAPBr can be used beyond the discussion of how to design values in games. Observing the students discussing the values, it raised the idea that an institution, whether public or private, can use the cards to discuss about values while training their staff or debating important values for their processes. VAPBr simplicity of use, with very flexible rules, allows for countless ways of use.

Additionally, the steps performed to build VAPBr can be reproduced to think about values for public services in different countries, based on national public policies and regulations. Therefore, we hope to be contributing to provide ways for improving citizen to government interactions and, mostly important, in a playful way.

\section{Acknowledgement}

Prof. Renata Araujo is partially supported by the Brazilian National Council for Scientific and Technological Development (CNPq) under grant 313210/2019-5 and by the Mackenzie Presbyterian University Research Fund. Prof. Tadeu Classe is supported by the State of Rio de Janeiro Research Support Foundation (FAPERJ) under grant E-26/010.002458/2019.

\section{References}

[1] UN, "United nations e-government survey. department of economic and social affairs," 2018, accessed 30 June 2020. [Online]. Available: https://publicadministration.un.org/ en/research/un-e-government-surveys

[2] OECD, “Digital government," 2020, accessed 30 June 2020. [Online]. Available: http://www.oecd.org/gov/digital-government

[3] D. Belanche, L. V. Casaló, and M. Guinaliu, "How to make online public services trustworthy," Electronic government, an international journal, vol. 9, no. 3, pp. 291-308, 2012. doi: 10.1504/EG.2012.048004

[4] T. Jäppinen, "How to manage a service innovation process in the public sector: from co-design to co-production," The Handbook of Service Innovation, pp. 707-726, 2015. doi: 10.1007/978-1-4471-6590-3_32

[5] J. Trischler, T. Dietrich, and S. Rundle-Thiele, "Co-design: from expert-to user-driven ideas in public service design," Public Management Review, vol. 21, no. 11, pp. 1595-1619, 2019. doi: 10.1080/14719037.2019.1619810

[6] CGI.Br, "Ict electronic government 2017: Survey on the use of information and communication technologies in the brazilian public sector," 2018, accessed 30 June 2020. [Online]. Available: https://www.cetic.br/media/docs/publicacoes/2/TIC_eGOV_ 2017_livro_eletronico.pdf 
[7] M. Buheji et al., "Re-inventing public services using gamification approaches," International Journal of Economics and Financial Issues, vol. 9, no. 6, pp. 48-59, 2019. doi: $10.32479 /$ ijefi.8803

[8] H. Wirman, "Serious games as social innovation: case hong kong 2003-2017," Cubic journal, 2018. doi: 10.31182/cubic.2018.1.011

[9] J. Aguilar, F. J. D. Serna, J. Altamiranda, J. Cordero, D. Chavez, and J. A. G. Mesa, "Metrópolis: un juego serio emergente en una ciudad inteligente," DYNA: revista de la Facultad de Minas. Universidad Nacional de Colombia. Sede Medellín, vol. 211, no. 86, pp. 215-224, 2019. doi: 10.15446/dyna.v86n211.8086

[10] L. Hassan, "Governments should play games: Towards a framework for the gamification of civic engagement platforms," Simulation \& Gaming, vol. 48, no. 2, pp. 249-267, 2017. doi: $10.1177 / 1046878116683581$

[11] S. Lounis, K. Pramatari, and A. Theotokis, "Gamification is all about fun: The role of incentive type and community collaboration," in 22nd European Conference on Information Systems, 2014, pp. 1-14.

[12] T. M. Classe, R. M. Araujo, G. B. Xexéo, and S. Siqueira, "The play your process method for business process-based digital game design," International Journal of Serious Games, vol. 6, no. 1, pp. 27-48, 2019. doi: 10.17083/ijsg.v6i1.269

[13] M. Flanagan, D. C. Howe, and H. Nissenbaum, "Embodying values in technology: Theory and practice," Information technology and moral philosophy, vol. 322, 2008. doi: 10.1017/CBO9780511498725.017

[14] M. Flanagan and H. Nissenbaum, Values at play in digital games. MIT Press, 2014.

[15] V. Çağdaş and E. Stubkjær, "Design research for cadastral systems," Computers, Environment and Urban Systems, vol. 35, no. 1, pp. 77-87, 2011. doi: 10.1016/j.compenvurbsys.2010.07.003

[16] N. Bayazit, "Investigating design: A review of forty years of design research," Design issues, vol. 20, no. 1, pp. 16-29, 2004. doi: 10.1162/074793604772933739

[17] D. Lathrop and R. Laurel, Open Government. Ot'Reilly Media, Inc, 2010.

[18] C. N. Cruz-Rubio, "Hacia el gobierno abierto: una caja de herramientas," 2014, accessed 04 September 2020. [Online]. Available: http://www.gigapp.org/index.php/ comunidad-gigapp/publication/show/1802

[19] C. G. Reddick, "Citizen-centric e-government," Homeland Security Preparedness and Information Systems: Strategies for Managing Public Policy. IGI Global, pp. 45-75, 2010. doi: 10.4018/978-1-60566-834-5.ch002

[20] R. Araujo and Y. Taher, "Refining it requirements for government-citizen coparticipation support in public service design and delivery," in Conference for EDemocracy and Open Government, Krems: DonauUniversität Krems, vol. 1, 2014, pp. 61-72.

[21] P. Bradwell and S. Marr, "Making the most of collaboration an international survey of public service co-design," Annual Review of Policy Design, vol. 5, no. 1, pp. 1-27, 2017.

[22] R. Araujo, Information Systems and the Open World Challenges. Boscarioli C., Araujo R.M., and Maciel R.S.P. I GranDSI-BR Grand Research Challenges in Information Systems in Brazil 2016-2026. Special Committee on Information Systems (CE-SI). Brazilian Computer Society (SBC), 2016, ch. 4, pp. 42-51.

[23] C. Boscarioli, R. M. Araujo, and R. S. P. Maciel, I GranDSI-BR Grand Research Challenges in Information Systems in Brazil 2016-2026. Porto Alegre: Special Committee on Information Systems (CE-SI). Brazilian Computer Society (SBC), 2017. ISBN 97885-7669-384-0

[24] GovInt, "Co-production - how does the co-production star toolkit help you? 
governance international," 2019, accessed 21 July 2020. [Online]. Available: http://www.govint.org/our-services/co-production/

[25] I. Laitinen, T. Kinder, and J. Stenvall, "Co-design and action learning in local public services," Journal of Adult and Continuing Education, vol. 24, no. 1, pp. 58-80, 2018. doi: 10.1177/1477971417725344

[26] E. Blomkamp, "Co-design for government: Magic bullet or magical thinking?" in Proc. 3rd Int. Conf. Public Policy (ICPP3), 2017, pp. 1-25.

[27] M. Dumas, M. La Rosa, J. Mendling, and H. A. Reijers, "Introduction to business process management," Fundamentals of business process management, pp. 1-31, 2013. doi: https://doi.org/10.1007/978-3-642-33143-5

[28] C. Cappelli, J. C. S. do Prado Leite, and A. d. P. A. Oliveira, "Exploring business process transparency concepts," in 15th IEEE International Requirements Engineering Conference (RE 2007). IEEE, 2007. doi: 10.1109/RE.2007.35 pp. 389-390.

[29] J. Becker, L. Algermissen, and T. Falk, Modernizing Processes in Public Administration: Process Management in the Age of e-Government and New Public Management. Springer-Verlag, Berlin, Heidelberg, 2012.

[30] H. R. M. Santos, G. A. Valença, and C. F. Alves, "Strategies for managing critical success factors of bpm initiatives in brazilian public organizations: a qualitative empirical study," iSys-Revista Brasileira de Sistemas de Informação, vol. 8, no. 1, pp. 42-64, 2015. doi: 10.5753/isys.2015.279

[31] A. Van Looy and J. Van den Bergh, "The effect of organization size and sector on adopting business process management," Business \& Information Systems Engineering, vol. 60, no. 6, pp. 479-491, 2018. doi: https://doi.org/10.1007/s12599-017-0491-3

[32] B. Niehaves and R. Malsch, "Democratizing process innovation? on citizen involvement in public sector bpm," in I8th International Conference on Electronic Government, Lecture Notes in Computer Science. Springer-Verlag, Berlin Heidelberg, 5693, 2009. doi: https://doi.org/10.1007/978-3-642-03516-6_21 pp. 245-256.

[33] W. Gong and M. Janssen, "The impact of social business process management on policy-making in e-government," in Proceedings of the 50th Hawaii International Conference on System Sciences, 2017. doi: https://doi.org/10.24251/HICSS.2017.297 pp. $2458-2467$.

[34] C. Alfaro, J. M. Lavın, J. Gomez, and D. R. R. Insua, "epbpm: A graphical language supporting interoperability of participatory process," in 2015 Second International Conference on eDemocracy \& eGovernment (ICEDEG). IEEE, 2015. doi: 10.1109/ICEDEG.2015.7114474 pp. 98-103.

[35] D. R. Michael and S. L. Chen, Serious games: Games that educate, train, and inform. Muska \& Lipman/Premier-Trade, 2005.

[36] J. Hamari, J. Koivisto, and H. Sarsa, "Does gamification work?-a literature review of empirical studies on gamification," in 2014 47th Hawaii international conference on system sciences. Ieee, 2014. doi: 10.1109/HICSS.2014.377 pp. 3025-3034.

[37] J. McGonigal, Reality is broken: Why games make us better and how they can change the world. Penguin, 2011.

[38] S.-K. Thiel, M. Reisinger, K. Röderer, and P. Fröhlich, "Playing (with) democracy: A review of gamified participation approaches," JeDEM-eJournal of eDemocracy and Open Government, vol. 8, no. 3, pp. 32-60, 2016. doi: 10.29379/jedem.v8i3.440

[39] T. Classe, R. Araujo, and G. Xexeo, "Desaparecidos rj-um jogo digital para o entendimento de processos de prestação de serviços públicos (english title: Desaparecidos rj - a digital game do public process service understanding)," in Brazilian Symposium of Games and Digital Entertainment (SBGames), 2017, pp. 772-781.

[40] M. Rokeach, The nature of human values. Free press, 1973. 
[41] S. H. Schwartz and W. Bilsky, "Toward a universal psychological structure of human values." Journal of personality and social psychology, vol. 53, no. 3, p. 550, 1987. doi: ttps://doi.org/10.1037/0022-3514.53.3.550

[42] J. Hessen, "Filosofia dos valores," Revista Portuguesa de Filosofia, 1945.

[43] S. Kheirandish, M. Funk, S. Wensveen, M. Verkerk, and M. Rautterbergh, "A comprehensive value framework for design," Technology in Society, vol. 62, p. 101302, 2020. doi: https://doi.org/10.1016/j.techsoc.2020.1013022

[44] S. Kheirandish, M. Funk, S. Wensveen, M. Rautterbergh, and M. Verkerk, "Huvalue: a tool to support design students in considering human values in their design," International Journal of Technology and Design Education, vol. 20, pp. 1015-1041, 2019. doi: https://doi.org/10.1007/s10798-019-09527-3

[45] M. S. Horn, "Beyond video games for social change," Interactions, vol. 21, no. 2, pp. 66-68, 2014. doi: https://doi.org/10.1145/2568372

[46] D. P. Darzentas and L. Urqyhart, "Interdisciplinary reflections on games and human values," in Proceedings of the 2015 Annual Symposium on Computer-Human Interaction in Play, 2015. doi: http://dx.doi.org/10.1145/2793107.2810259 pp. 805-810.

[47] J. Belman, H. Nissenbaum, M. Flanagan, and J. Diamond, "Grow-a-game: A tool for values conscious design and analysis of digital games," in DiGRA Conference, vol. 6, 2011, pp. 1-15.

[48] S. Kheirandish and M. Rauterberg, "Human value based game design," in 2018 2nd National and 1st International Digital Games Research Conference: Trends, Technologies, and Applications (DGRC). IEEE, 2018. doi: 10.1109/DGRC.2018.8712077 pp. 6-16.

[49] M. Raftopoulos, "Playful card-based tools for gamification design," in Proceedings of the annual meeting of the Australian special interest group for computer human interaction, 2015. doi: 10.1145/2838739.2838797 pp. 109-113.

[50] H. A. Simon, The sciences of the artificial. MIT press, 2019.

[51] A. Hevner, S. March, J. Park, and S. Ram, "Design science in information systems research. 2004." MIS Quarterly, 2004. doi: https://doi.org/10.2307/25148625

[52] M. Pimentel, D. Filippo, and T. M. Santos, "Design science research: pesquisa científica atrelada ao design de artefatos," RE@ D-Revista de Educação a Distância e Elearning, vol. 3, no. 1, pp.37-61, 2020.doi: 10.34627/re@d_le@d.v3i1.203

[53] K. Peffers, T. Tuunanen, M. A. Rothenberger, and S. Chatterjee, "A design science research methodology for information systems research," Journal of management information systems, vol. 24, no. 3, pp. 45-77, 2007. doi: https://doi.org/10.2753/MIS07421222240302

[54] A. Magdaleno and R. Araujo, "Ecossistemas digitais para o apoio a sistemas de governo abertos e colaborativos (english title: Digital ecosystems to support the open and collaborative governments)," in Anais do XI Simpósio Brasileiro de Sistemas de Informação. SBC, 2015, pp. 655-658.

[55] P. Scerb, "Cause or consequence? representation and participation in the bolsonarist counter movement to the crisis of democracy in brazil," Mediações-Revista de Ciências Sociais, vol. 26, no. 1, pp. 68-85, 2021. doi: https://doi.org/10.5433/21766665.2021.1v26n1p68

[56] V. R. Basili, "Software modeling and measurement: the goal/question/metric paradigm," University of Maryland, Tech. Rep. CS-TR-2956, UMIACS-TR-92-9, 1992.

[57] ICRC, "Brazil: 82,094 people registered as missing in 2018: families need answers. international committee of the red cross," 2018, accessed 21 July 2020. [Online]. Available: https://bit.ly/IRCRMissingBrazil 
pag. 46

[58] F. D. Davis, "Perceived usefulness, perceived ease of use, and user acceptance of information technology," MIS quarterly, pp. 319-340, 1989. doi: https://doi.org/10.2307/249008

[59] R. Yin, Case study research: design and methods. Sage Publications, Inc, 2003. 


\section{Appendix 1: VAPBr Cards Description in Details}

\begin{tabular}{|c|c|c|}
\hline Card & Brief Description & Extended Description \\
\hline Accountability & $\begin{array}{l}\text { Allow verification of actions and } \\
\text { expenses }\end{array}$ & $\begin{array}{l}\text { The } 1988 \text { Federal Constitution guarantees citizens access to } \\
\text { public data generated and maintained by the government. It is } \\
\text { the right of every citizen to access, for example, from where } \\
\text { State revenues come, how taxes are spent, among other data. } \\
\text { The duty of publicity and transparency requires that adminis- } \\
\text { trative information is available to citizens quickly and simply }\end{array}$ \\
\hline Legality & Act according to the law & $\begin{array}{l}\text { The principle of legality is one of the bases of the Brazilian } \\
\text { Constitution, as it protects the citizen from abusive actions by } \\
\text { the State. The principle of legality ensures that only laws can } \\
\text { create obligations on people; that is, the state can only demand } \\
\text { that you do or stop doing something if that requirement is writ- } \\
\text { ten by law }\end{array}$ \\
\hline Security & Condition of being free from hazard & $\begin{array}{l}\text { Public security, the duty of the State, the right and responsibil- } \\
\text { ity of all, is exercised for the preservation of public order and } \\
\text { exemption from danger to people and property. }\end{array}$ \\
\hline Efficiency & $\begin{array}{l}\text { Achieve the result with minimal } \\
\text { loss of resources }\end{array}$ & $\begin{array}{l}\text { It is what imposes on the public administration and its agents } \\
\text { the pursuit of the common good, through the exercise of their } \\
\text { powers in an impartial, neutral, transparent, participatory, ef- } \\
\text { fective way, without bureaucracy and always in search of qual- } \\
\text { ity, moving towards the adoption of the legal and moral criteria } \\
\text { necessary for the best possible use of public resources, avoid- } \\
\text { ing waste }\end{array}$ \\
\hline Simplicity & $\begin{array}{l}\text { Be clear and understandable to most } \\
\text { people }\end{array}$ & $\begin{array}{l}\text { Simplicity is the state or quality of being simple. Something } \\
\text { easy to understand or explain and which appears to be simple, } \\
\text { in contrast to something complicated }\end{array}$ \\
\hline Justice & $\begin{array}{l}\text { The character of what is fair, impar- } \\
\text { tial }\end{array}$ & $\begin{array}{l}\text { Access to justice constitutes the right to plead with the State to } \\
\text { solve conflicts and the right to a fair, effective, and reasonably } \\
\text { long process. In parallel with it, due to the legal process, there } \\
\text { must be a set of other guarantees that will limit the exercise of } \\
\text { power by the judge and opportunities provided by law. }\end{array}$ \\
\hline Privacy & $\begin{array}{l}\text { Right to control public information } \\
\text { about you }\end{array}$ & $\begin{array}{l}\text { The purpose of item } \mathrm{X} \text { of } \mathrm{CF} 88 \text { is to protect peoples privacy, } \\
\text { honor and image, guaranteeing their right to compensation for } \\
\text { any damages caused by the violation of these rights. While } \\
\text { "intimacy" refers to the circle of the individualt's closest rela- } \\
\text { tionships, such as relationships with family members, "private } \\
\text { life" refers to the individuals relationship with society in gen- } \\
\text { eral. }\end{array}$ \\
\hline Equality & Equal rights without exclusion & $\begin{array}{l}\text { The principle of equality provides equal skills and virtual pos- } \\
\text { sibilities for citizens to enjoy equal treatment under the law. } \\
\text { This principle prohibits arbitrary and absurd differentiation, } \\
\text { not justified by the values of the Federal Constitution, and aims } \\
\text { at limiting the role of the legislator, the interpreter or public au- } \\
\text { thority and the private individual }\end{array}$ \\
\hline Gender equity & Gender equity & $\begin{array}{l}\text { When we talk about gender equity, we are talking about jus- } \\
\text { tice, equal opportunities regardless of gender. The discourse } \\
\text { of equality starts from the idea that we must treat everyone } \\
\text { equally in the sense of plurality and diversity }\end{array}$ \\
\hline Diversity & Respect for difference & $\begin{array}{l}\text { It goes beyond gender equity. Diversity means variety, plu- } \\
\text { rality, difference. It gathers everything that presents multiple } \\
\text { aspects different from each other: cultural, sexual, biological, } \\
\text { ethnic, linguistic, religious, etc. }\end{array}$ \\
\hline Inclusion & To be part & $\begin{array}{l}\text { Social inclusion is the set of measures, policies, or actions that } \\
\text { aim to equalize excluded people or groups in society. }\end{array}$ \\
\hline Democracy & $\begin{array}{l}\text { "Government of the people, by the } \\
\text { people and for the people" }\end{array}$ & $\begin{array}{l}\text { Democracy is a political regime in which all eligible citizens } \\
\text { participate equally - directly or through elected representatives } \\
\text { - in the proposal, development and creation of laws. It encom- } \\
\text { passes the social, economic and cultural conditions that allow } \\
\text { the free and equal exercise of political self-determination. }\end{array}$ \\
\hline
\end{tabular}




\begin{tabular}{|c|c|c|}
\hline $\begin{array}{c}\text { Social } \\
\text { Participation }\end{array}$ & $\begin{array}{l}\text { Allow individuals to influence the } \\
\text { organization of society }\end{array}$ & $\begin{array}{l}\text { It is an evolution of democracy. CF88 guaranteed societys par- } \\
\text { ticipation in the management of policies and programs pro- } \\
\text { moted by the Federal Government - Its called social control. } \\
\text { In the Executive branch, popular participation occurs through } \\
\text { councils and public policy management committees (Councils } \\
\text { for Social Assistance, Health, Education, among others). In } \\
\text { the legislative branch, citizens can participate by voting. In the } \\
\text { Judiciary, participation can take place through a popular jury } \\
\text { to judge crimes. }\end{array}$ \\
\hline Dignity & $\begin{array}{l}\text { Recognition of being treated with } \\
\text { respect }\end{array}$ & $\begin{array}{l}\text { Examples of rights that constitute a requirement and the ful- } \\
\text { fillment of the dignity of the human person: personality rights, } \\
\text { the right to physical and psychological integrity, the general } \\
\text { right to equality, the right to life, civil and political freedoms, } \\
\text { procedural rights and guarantees, social rights, economic and } \\
\text { cultural }\end{array}$ \\
\hline Cooperation & $\begin{array}{l}\text { Joint operation to achieve a com- } \\
\text { mon good }\end{array}$ & $\begin{array}{l}\text { BFC } 88 \text { provides for cooperation between people for the } \\
\text { progress of humanity. It also deals with technical and finan- } \\
\text { cial cooperation between the Union and the States, the Federal } \\
\text { District and the Municipalities, intending to balance develop- } \\
\text { ment and national well-being; in pre-school and elementary } \\
\text { education programs; in addition to population health care ser- } \\
\text { vices }\end{array}$ \\
\hline Creativity & Right to express opinions freely & $\begin{array}{l}\text { The expression of intellectual, artistic, scientific and commu- } \\
\text { nication activity is unrestricted, regardless of censorship or li- } \\
\text { cense. }\end{array}$ \\
\hline Impersonality & $\begin{array}{l}\text { It does not refer to one person in } \\
\text { particular but people in general }\end{array}$ & $\begin{array}{l}\text { The term impersonality has the meaning of prohibiting differ- } \\
\text { entiated treatments and personal favors. The public adminis- } \\
\text { trator must treat everyone equally, achieving a single objective, } \\
\text { the public interest, and cannot serve the private interests of spe- } \\
\text { cific people or some economic groups }\end{array}$ \\
\hline Innovation & Ability to generate news & $\begin{array}{l}\text { The State must stimulate the formation and strengthening of } \\
\text { innovation in companies, as well as in other entities, public } \\
\text { or private, the establishment and maintenance of parks and } \\
\text { technological centers and different environments that promote } \\
\text { innovation, the performance of independent inventors and the } \\
\text { creation, absorption, diffusion and transfer of technology }\end{array}$ \\
\hline Freedom & Power of choice guarantee & $\begin{array}{l}\text { As for freedom, they permeate most of the items of article 5, } \\
\text { being protected, most notably, in items IV (Free Expression } \\
\text { of Thought), VI (Religious Freedom), XV (Freedom of Move- } \\
\text { ment) and XVII (Freedom of Association }\end{array}$ \\
\hline
\end{tabular}

